\title{
Repeated Lofexidine Treatment Attenuates Stress-Induced, But not Drug Cues-Induced Reinstatement of a Heroin-Cocaine Mixture (Speedball) Seeking in Rats
}

\author{
D. Highfield, Ph.D., J. Yap, B.A., J.W. Grimm, Ph.D., U. Shalev, Ph.D., and Y. Shaham, Ph.D.
}

\begin{abstract}
Alpha-2 adrenoceptor agonists (lofexidine, clonidine) are used to alleviate short-term opioid withdrawal in humans. In rats, acute injections of these agents attenuate stressinduced reinstatement of heroin and cocaine seeking at time points that are beyond the acute drug withdrawal phase. Here, we studied whether exposure to lofexidine would attenuate reinstatement of a heroin-cocaine mixture (speedball) seeking induced by exposure to stress or to drugassociated cues. Rats were trained to lever press for speedball for 10 days, and the drug-reinforced behavior was then extinguished for 11 days in the presence (Experiment 1) or the absence (Experiment 2) of the drug cues.

Subsequently, rats were tested for reinstatement of drug seeking after exposure to intermittent footshock stress (5-15 min; Experiment 1) or the drug cues (Experiment 2).
\end{abstract}

Starting on day 7 of training, rats received daily injections of saline or lofexidine ( 0.1 or $0.2 \mathrm{mg} / \mathrm{kg}$ ). Repeated lofexidine treatment significantly attenuated footshockinduced reinstatement, but did not alter drug cues-induced reinstatement of speedball seeking. In addition, lofexidine did not have a consistent effect on speedball selfadministration and extinction behavior. Results extend previous reports with acute drug injections, indicating that lofexidine maintains its effect on stress-induced reinstatement after repeated treatment. The present data also suggest that the neurochemical events underlying stress- and drug cues-induced relapse are not identical. [Neuropsychopharmacology 25:320-331, 2001] (c) 2001 American College of Neuropsychopharmacology. Published by Elsevier Science Inc.
KEY WORDS: Alpha-2 adrenoceptor agonists; Cocaine; Drug self-administration; Extinction; Heroin; Reinstatement; Relapse; Stress

A number of studies reported that a significant proportion of drug addicts use both heroin and cocaine, including a heroin-cocaine combination, speedball (Hoff-

From the Behavioral Neuroscience Branch, IRP/NIDA, Baltimore, MD.

Address correspondence to: Dr. Yavin Shaham, Behavioral Neuroscience Branch, IRP/NIDA/NIH, 5500 Nathan Shock Drive, Baltimore, MD 21224.

Received January 24, 2000; revised December 19, 2000; accepted January 8, 2001.

Online publication: 1/11/01 at www.acnp.org/citations/Npp 01120167. man et al. 1998; Schutz et al. 1998). At present, no effective medications exist for the treatment of this type of polydrug use (Mendelson and Mello 1996). Preclinical studies reported that speedball is readily self-administered in rats (Duvauchelle et al. 1998; Hemby et al. 1996) and monkeys (Mello et al. 1995; Rowlett et al. 1999). It was also found that while opioid and dopamine (DA) receptor antagonists have some effects on speedball self-administration (Hemby et al. 1996; Negus and Mello 1998; Rowlett et al. 1999), a more effective way to attenuate speedballmaintained behavior is to block both opioid and DA receptors (Mello and Negus 1999). These data indicate that both receptor types are involved in the maintenance of speedball self-administration behavior and are in concordance with previous studies on the pharma- 
cology of heroin and cocaine reinforcement (Ettenberg et al. 1982). Recent studies have shown that speedball injections increase DA levels in the nucleus accumbens (NAc), a brain area involved in the reinforcing effects of abused drugs (Wise 1996), to a much greater degree than either heroin or cocaine alone (Hemby et al. 1999; Zernig et al. 1997). This synergistic effect may account for the reinforcing effects of speedball in humans and nonhumans (Hemby et al. 1999).

The preclinical studies described above concentrated on the neurobiology of speedball-maintained behavior during drug self-administration. At present, however, no studies examined factors involved in relapse to speedball seeking. Relapse to drug use after periods of abstinence is common in heroin, cocaine and speedball users (Mendelson and Mello 1996; O’Brien 1997). An animal model used to study factors involved in relapse to drug seeking is the reinstatement procedure. In this model, the effect of exposure to drugs or non-drug stimuli on reinstatement of drug seeking is examined after training for drug self-administration and subsequent extinction of drug-reinforced behavior (Stewart and de Wit 1987). The reinstatement procedure appears to have good predictive validity. Exposure to drugs, drug-related cues and stressors were found to increase drug craving and relapse to drug use in humans (Childress et al. 1992; de Wit 1996; Ludwig et al. 1974; Sinha et al. 1999). Using the reinstatement model in rats, these same conditions were found to reinstate drug seeking after prolonged withdrawal periods (De Vries et al. 1999; Meil and See 1996; Shaham et al. 2000a; TranNguyen et al. 1998).

Here, we studied whether footshock stress and drugassociated cues would reinstate drug seeking in rats with a history of speedball self-administration. In Experiment 1 , we used a reinstatement procedure in which it was found that exposure to footshock stress reinstates heroin (Shaham and Stewart 1995) and cocaine (Erb et al. 1996) seeking. In Experiment 2, we used a procedure developed by See and colleagues for studying the effect of reexposure to drug-paired cues on relapse (Meil and See 1996). In this procedure, which is based in part on previous work (Davis and Smith 1976), each drug infusion during the training phase is paired with a compound tone + light cue. Subsequently, the drug is removed and the lever-pressing behavior is extinguished in the absence of the drug-paired cue. The rats are then tested for resumption of drug seeking in a session in which lever presses lead to the delivery of the drug-paired cue.

We also studied the effect of repeated exposure to the alpha-2 adrenoceptor agonist, lofexidine, on reinstatement induced by either footshock stress or drug cues. Acute injections of low doses of alpha-2 adrenoceptor agonists (clonidine [0.01- $-0.04 \mathrm{mg} / \mathrm{kg}$ ] or lofexidine [0.05-0.2 $\mathrm{mg} / \mathrm{kg}]$ ) attenuate footshock stress-induced reinstatement of heroin and cocaine seeking in rats (Erb et al. 2000; Shaham et al. 2000b). Alpha-2 adrenoceptor agonists inhibit norepinephrine (NE) cell firing (Aghajanian and VanderMaelen 1982) and release (Carter 1997). At the doses used in the reinstatement studies, clonidine and lofexidine decrease NE release under basal conditions, and block footshock-induced NE release in the prefrontal cortex and the amygdala (Erb et al. 2000). These data suggest that activation of NE systems in the brain, known to be involved in stress responses (Stanford 1995), is involved in stress-induced reinstatement of drug seeking.

In humans, lofexidine and clonidine are used to alleviate short-term opioid withdrawal symptoms (Gold and Kleber 1979; Lin et al. 1997), but relapse rates after detoxification are high (Herman and O'Brien 1997). The above findings in rats, obtained at time periods that are beyond the acute withdrawal phase, suggest that alpha2 adrenoceptor agonists might be useful for the prevention of relapse to heroin and cocaine after prolonged drug-free periods. In previous studies, however, clonidine or lofexidine were given acutely during tests for reinstatement in rats that were previously trained to self-administer either heroin or cocaine. Thus, the relevance of these data to the human situation, where medications are often taken for long periods and people typically use more than one drug, remains to be determined. We, therefore, studied whether lofexidine would prevent stress-induced reinstatement of speedball seeking after repeated treatment. For comparison purposes, we also tested the effect of repeated lofexidine treatment on cue-induced reinstatement.

\section{MATERIALS AND METHODS}

\section{Subjects}

Male Long-Evans rats (Charles River, Raleigh, NC) weighing 350-400 g were used. Rats were given 1-2 weeks to acclimate to the animal housing facility before surgery and were transferred to the self-administration boxes 5-7 days after surgery. Rats lived in these boxes for $24 \mathrm{hr} /$ day and were maintained on a reversed lightdark cycle (lights on 10:00 pm to 10:00 am) with water and food freely available. The procedures followed the "Principles of laboratory animal care" (NIH publication No. 86-23 1996) and were approved by the local Animal Care and Use Committee.

\section{Surgery}

Rats were surgically implanted with intravenous (IV) Silastic catheters (Dow Corning, Midland, MI) into the right jugular vein under anesthesia (xylazine [10 mg/ $\mathrm{kg}$, i.p.] + ketamine $\mathrm{HCl}$ [100 mg/kg, i.p.]). The analgesic buprenorphine $(0.01 \mathrm{mg} / \mathrm{kg}$, s.c. $)$ was also given at 
the time of surgery. The catheter was secured to the vein with a silk suture and passed subcutaneously to the top of the skull, where it was connected to a modified 22-gauge cannula (Plastics One, Roanoke, VA). The cannula was mounted to the skull with jeweler screws and dental cement. Catheters were flushed every 24-48 hr with sterile saline $(0.05 \mathrm{ml})$ and body weight was measured daily.

\section{Apparatus}

The self-administration boxes had two levers located 9 $\mathrm{cm}$ above the floor, but only one lever (an active, retractable lever; Med Associates, Georgia, VT) activated the infusion pump (Razel Sci., Stamford, CT). Presses on the other lever (an inactive, stationary lever) were also recorded. The grid floors of the chambers were connected to electric shock generators (Med Associates).

\section{Drugs}

Cocaine $\mathrm{HCl}$ and Diacetylmorphine $\mathrm{HCl}$ (heroin) were obtained from NIDA/NIH and were dissolved in sterile saline. The heroin-cocaine mixture was infused at a volume of $0.13 \mathrm{ml}$ over $4.5 \mathrm{sec}$. Lofexidine (Britannia Pharmaceuticals, Surrey, UK) was dissolved in sterile saline and was injected, i.p., at a volume of $1 \mathrm{ml} / \mathrm{kg}$.

\section{Procedures}

Experiment 1: stress-induced reinstatement. The experiment consisted of three phases: self-administration training (10 days), extinction of drug self-administration (11 days), and tests for reinstatement. Ten of the 39 rats were excluded due to poor health $(n=2)$, overdose $(n=1)$, loss of head cap during training $(n=2)$, catheter blockade during training $(n=4)$, or extreme extinction behavior $(n=1,125$ lever presses $/ 3 \mathrm{hr}$ on day 11 of extinction).

TRAINING PHASE. Rats were trained to self-administer speedball $(0.025 \mathrm{mg} / \mathrm{kg} /$ inf of heroin $+0.25 \mathrm{mg} /$ $\mathrm{kg} /$ inf of cocaine, IV, fixed ratio-1 schedule, 20-sec timeout) for two 3-hr sessions per day. Session 1 started at the onset of the dark period and Session 2 started $3 \mathrm{hr}$ after the end of Session 1. Speedball was given for two sessions/day in order to evaluate possible delayed effects of lofexidine, given prior to Session 1 (see below), on drug self-administration and extinction behavior.

Each session began with the introduction of the retractable lever into the cage and the illumination of a white cue light above the active lever for $30 \mathrm{sec}$. A red houselight was also illuminated at the start of each session and it remained on for the entire session. After each drug infusion, the cue light was illuminated for 20 sec (the timeout period). On day 6 of training, rats were given a saline injection $(1 \mathrm{ml} / \mathrm{kg}$, i.p.), $1 \mathrm{hr}$ before Ses- sion 1. Rats were then divided into 3 groups $(n=9-10$ per group) that were given saline or lofexidine (0.1 or $0.2 \mathrm{mg} / \mathrm{kg}$, i.p.) $1 \mathrm{hr}$ before Session 1 on days 7 to 10 of training, days $1-11$ of the extinction phase, and during the first test for footshock-induced reinstatement (see below).

EXTINCTION PHASE. During the extinction phase, the drug syringes were removed, but the rest of the conditions remained the same as in training. Saline or lofexidine $(0.1$ or $0.2 \mathrm{mg} / \mathrm{kg}$ ) was injected $1 \mathrm{hr}$ before Session 1 throughout the 11 days of extinction.

TESTS FOR REINSTATEMENT. Two tests for footshock-induced reinstatement were conducted. On the first test, rats were given the same saline or lofexidine pretreatment they received during training and extinction. On the second test, the conditions were reversed: the group previously pretreated with saline was given lofexidine $(0.2 \mathrm{mg} / \mathrm{kg})$, whereas the groups previously pretreated with lofexidine were given saline.

First Test for Reinstatement. On two separate days, rats were pretreated with saline or lofexidine $(0.1$ or $0.2 \mathrm{mg} /$ $\mathrm{kg}) 1 \mathrm{hr}$ before Session 1, and were given intermittent footshock ( 5 or $15 \mathrm{~min}$, counterbalanced, $0.6 \mathrm{~mA}, 0.5 \mathrm{sec}$ $\mathrm{ON}$, a mean OFF period of $40 \mathrm{sec}$ ) just prior to the start of the session. Rats were not given shock or lofexidine prior to Session 2. The data from the last day of extinction served as the baseline, no stress condition for the statistical analysis.

Second Test for Reinstatement. After the first test, rats were retested for reinstatement induced by footshock $(0,5$ and $15 \mathrm{~min})$ during a 3-day period. On day 1 , the two groups previously pretreated with lofexidine were injected with saline $1 \mathrm{hr}$ prior to Session 1 in the absence of shock, whereas the group previously pretreated with saline was given lofexidine $(0.2 \mathrm{mg} / \mathrm{kg})$. On days 2 and 3 , the rats were given the same pretreatment they received on day 1 and tested for reinstatement induced by intermittent footshock (5 or $15 \mathrm{~min}$, counterbalanced) as described above. Thus, we determined whether acute lofexidine pretreatment would attenuate footshock-induced reinstatement in rats previously exposed to the stressor in the absence of lofexidine. Due to a technical error, data were lost for four subjects during Session 2 on one of the test days.

Experiment 2: Cue-Induced Reinstatement. The experiment consisted of three phases: self-administration training (10 days), extinction of operant responding (11 days), and test for reinstatement. Six of the 28 subjects were excluded due to poor health $(n=1)$, accidental overdose due to instrument failure $(n=1)$, catheter blockade during training $(n=3)$, or unusual extinction behavior $(n=1$, higher responses on the active lever on Day 11 [37 responses $/ 3 \mathrm{hr}$ ] than on Day 1 of the extinction phase [13 responses $/ 3 \mathrm{hr}]$ ). 
TRAINING PHASE. Rats were trained to self-administer speedball as described above for Experiment 1, with the exception that after each drug infusion a tone (20 $\mathrm{dB}$ above background noise level) and the cue light were presented for the first $5 \mathrm{sec}$ of the $20-\mathrm{sec}$ timeout period. On day 6 of training, rats were given a saline injection $(1 \mathrm{ml} / \mathrm{kg}$, i.p.) before Session 1 . Rats were then divided into three groups ( $n=7-8$ per group) that were given saline or lofexidine injections $(0.1$ or $0.2 \mathrm{mg} / \mathrm{kg}) 1$ hr before Session 1 during days 7-10 of training, days 111 of extinction and during test for reinstatement.

Extinction Phase. During the extinction phase, the drug syringes were removed and the tone + light cue was not presented after the lever presses (i.e., the operant lever-pressing behavior was extinguished in the absence of the compound cue that was paired with drug infusions). Saline or lofexidine was injected $1 \mathrm{hr}$ before Session 1 throughout the extinction phase.

TEST FOR REINSTATEMENT. The test for cue-induced reinstatement was conducted $24 \mathrm{hr}$ after day 11 of extinction. Rats were given saline or lofexidine $1 \mathrm{hr}$ before Session 1. All rats were given "priming" exposure to the cue (the light + tone cue was presented twice for $5 \mathrm{sec}$ at the start of the session). For the rest of the test session, lever presses led to cue presentation. Rats were not exposed to the tone + light cue during Session 2. The data from the last day of extinction served as the baseline, no cue condition for the statistical analysis.

The day after testing, rats were given extinction sessions during the two-daily sessions and received the daily injections of lofexidine or saline before Session 1. On the last two days of the experiment, rats that had maintained patent catheters (saline condition, $n=5 ; 0.1 \mathrm{mg}$ / $\mathrm{kg}$ lofexidine, $n=3 ; 0.2 \mathrm{mg} / \mathrm{kg}, n=8$ ) received their regular injections of lofexidine or saline prior to the start of Session 1 and were then allowed to lever press for speedball under the same conditions as in training. Thus, we determined whether repeated exposure to lofexidine throughout days 7-10 of training, extinction and testing would alter subsequent speedball self-administration.

\section{Effect of Lofexidine on Sensitivity to Shock}

At the end of Experiment 1, eight rats were injected with saline and 10 rats were injected with lofexidine $(0.2 \mathrm{mg} / \mathrm{kg})$ and their sensitivity to footshock was determined $1 \mathrm{hr}$ later. This was done by determining the threshold intensity for inducing the withdrawal of the hind paw from the grid floor after exposure to discrete $0.5 \mathrm{sec}$ footshocks. The shocks were given in an ascending order, starting at $0.05 \mathrm{~mA}$ with $0.05 \mathrm{~mA}$ increments.

\section{Statistical Analyses}

Data were analyzed separately for the training, extinction and reinstatement phases and separately for Ses- sion 1 and Session 2. During training, the dependent measures were speedball infusions and inactive lever responses. During extinction and reinstatement, the dependent measures were total responses on the previously active lever and inactive lever responses.

Experiment 1. The repeated measures ANOVAs for the training and extinction phases included the withinsubjects factor of Day (days 7-10 of training or days 1-11 of extinction) and the between-subjects factor of Lofexidine Dose $(0,0.1$, or $0.2 \mathrm{mg} / \mathrm{kg})$. For the first test for reinstatement, the statistical analysis included the within-subjects factor of Shock Duration (0 [data from day 11 of extinction], 5, and $15 \mathrm{~min}$ ) and the between-subjects factor of Lofexidine Dose. For the second test, the withinsubjects factor was Shock Duration $(0,5$, and $15 \mathrm{~min})$ and the between- subjects factor was Lofexidine Dose.

Experiment 2. The repeated measures ANOVAs for the training and extinction phases included the withinsubjects factor of Day and the between-subjects factor of Lofexidine Dose. For the testing phase, the statistical analysis included the within-subjects factor of Cue (not available [data from day 11 of extinction] and cue available) and the between-subjects factor of Lofexidine Dose. Post-hoc analyses were done with the Fisher-PLSD test and differences are reported for $p>.05$.

\section{RESULTS}

\section{Experiment 1: Stress-Induced Reinstatement}

Training Phase. Rats rapidly acquired speedball selfadministration during days 1-5 of training (data not shown). The effect of lofexidine or saline injections on speedball self-administration during Session 1 of days 7-10 of training is presented in Figure 1a.

SESSION 1. Lofexidine pretreatment $(1 \mathrm{hr})$ had a modest, non-significant effect on speedball infusions earned (Day by Lofexidine Dose, F[6,78] = 1.9, $p=.08$ ). Inactive lever responses were low (less than $3 /$ session) and no group differences were observed (data not shown).

SESSION 2. Due to technical problems (disconnection of infusion lines), five data points from different rats were excluded. Lofexidine pretreatment $(7 \mathrm{hr})$ had no effect on speedball infusions earned (Lofexidine Dose, $\mathrm{F}[2,26]=0.5, \mathrm{~ns})$. Inactive lever responses were low (less than 7 /session) and no group differences were observed (data not shown).

Extinction Phase. The effect of lofexidine or saline injections on extinction behavior during Session 1 is presented in Figure 2a.

SESSION 1. Lofexidine pretreatment (1 hr) had no effect on responses on the previously active lever 

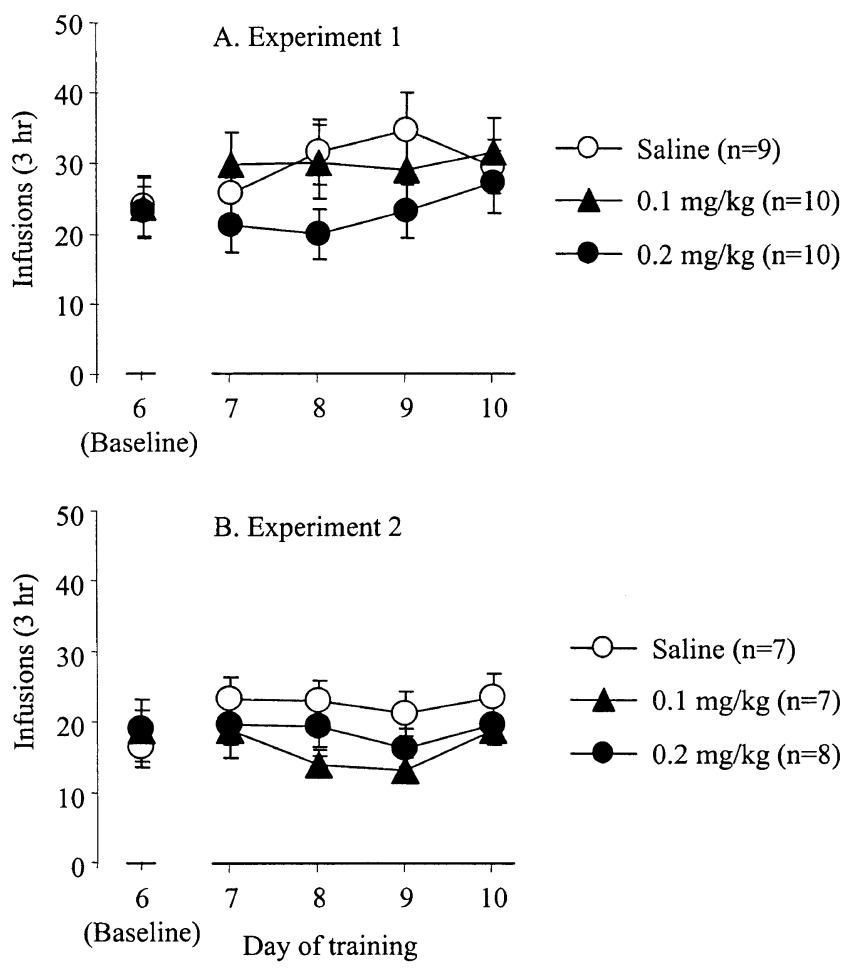

Figure 1. Training phase. Mean \pm SEM number of speedball infusions on the first 3-hr daily session (Session 1) during days 6 to 10 of the training phase: (A) Experiment 1 (stress-induced reinstatement); (B) Experiment 2 (cueinduced reinstatement). On days $7-10$, rats were given saline or lofexidine injections $1 \mathrm{hr}$ prior to the session (Experiment $1, n=9-10$ per dose; Experiment 2, $n=7-8$ per dose). On day 6 , all rats were given saline injections $1 \mathrm{hr}$ prior to the session.

(Lofexidine Dose, $\mathrm{F}[2,26]=1.3, \mathrm{~ns})$. An effect of Extinction Day $(\mathrm{F}[10,260]=28.5, p<.01)$ was observed; all groups reduced lever pressing over time. Inactive lever responses were low (less than 6/session) and no group differences were observed (data not shown).

SESSION 2. Lofexidine pretreatment $(7 \mathrm{hr})$ had some effect on responses on the previously active lever (Extinction Day by Lofexidine Dose, $\mathrm{F}[20,260]=2.0, p<$ .01) (data not shown). This effect is due to the shallow decrease in response rate in the $0.1-\mathrm{mg} / \mathrm{kg}$-group over time, and the somewhat higher response rate in the 0.2$\mathrm{mg} / \mathrm{kg}$-group toward the end of the extinction phase as compared with the saline group. Statistically significant group differences, however, were only observed on day 8 of extinction, but not on any of the other days. We interpret these data to indicate that lofexidine does not have a consistent effect on extinction behavior.

Responses on the inactive lever were somewhat higher in rats exposed to lofexidine (Lofexidine Dose $(\mathrm{F}[2,26]=3.6, p<.05)$. The means \pm SEM of responses / session for the 11 extinction days were $1.7 \pm 0.5,5.5 \pm$ 2.1 , and $4.9 \pm 2.0$ for the saline, $0.1-\mathrm{mg} / \mathrm{kg}$ and $0.2-\mathrm{mg} /$
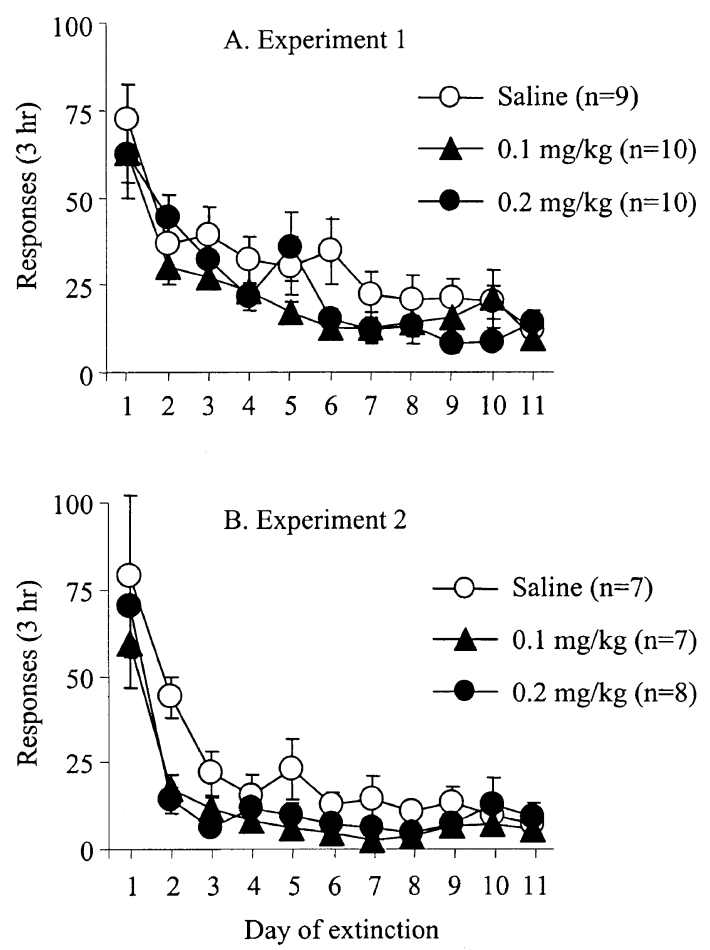

Figure 2. Extinction phase. Mean \pm SEM number of nonreinforced responses on the previously active lever on the first 3-hr daily session (Session 1) during days 1-11 of the extinction phase: (A) Experiment 1 (stress-induced reinstatement); (B) Experiment 2 (cue-induced reinstatement). The rats were given saline or lofexidine injections $1 \mathrm{hr}$ prior to the session (Experiment 1, $n=9-10$ per dose; Experiment 2, $n=7-8$ per dose). In Experiment 1, the extinction conditions were identical to the training conditions, with the exception that the speedball syringes were removed. In Experiment 2, the speedball syringes were removed and a tone + light compound cue that was previously paired with drug infusions after lever presses was not delivered.

$\mathrm{kg}$ groups, respectively. The reasons for this effect are not clear.

Tests for Reinstatement. The effect of lofexidine or saline on responses on the previously active lever and the inactive lever during tests for reinstatement are presented in Figures 3 and 4. Figure 3 shows the effect of repeated exposure to lofexidine or saline on reinstatement after exposure to intermittent footshock or no shock. Figure 4 shows the effect of acute exposure to lofexidine $(0.2 \mathrm{mg} / \mathrm{kg})$ during the second test for reinstatement after the pretreatment conditions were reversed (i.e., rats previously repeatedly exposed to saline were given lofexidine $[0.2 \mathrm{mg} / \mathrm{kg}]$, while rats previously repeatedly exposed to lofexidine were given saline).

First Test for ReInstatement. Session 1. Exposure to footshock increased responding on the previously active lever in saline-treated rats (Shock Duration, 

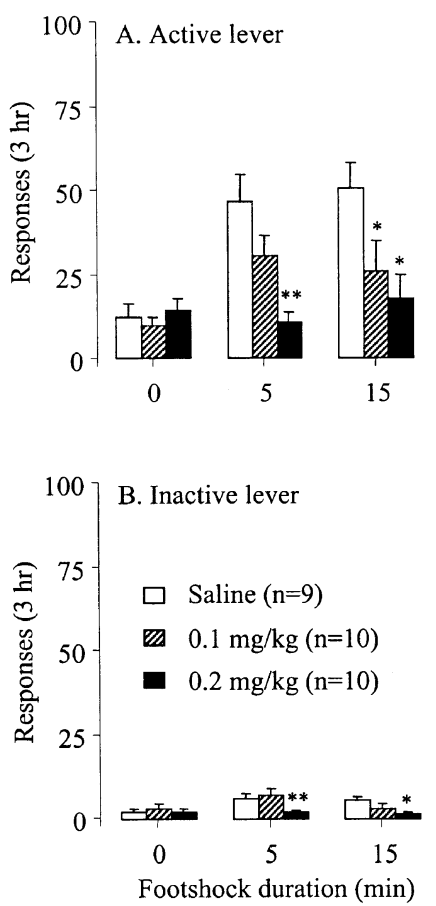

Figure 3. Experiment 1: First test for stress-induced reinstatement - repeated lofexidine injections. Mean \pm SEM number of non-reinforced responses on (A) the previously active lever and on (B) the inactive lever during the first 3-hr daily session (Session 1) after no shock and exposure to 5 and 15 min of intermittent footshock. Rats were pretreated with saline or lofexidine during days 7-10 of training, the extinction phase and during testing. Saline or lofexidine were given $1 \mathrm{hr}$ prior to testing ( $n=9-10$ per dose) and footshock was administered just prior to the start of Session 1. * Different from the saline condition, $p<.05$. ${ }^{* *}$ Different from the saline and the $0.1 \mathrm{mg} / \mathrm{kg}$-lofexidine conditions, $p<.05$.

$\mathrm{F}[2,52]=13.1, p<.01)$. This effect was attenuated by lofexidine (Lofexidine Dose, $\mathrm{F}[2,26]=6.8, p<.01$; Shock Duration by Lofexidine Dose, $\mathrm{F}[4,52]=4.6, p<.01)$. Responding on the inactive lever was somewhat decreased by lofexidine (Lofexidine Dose, $\mathrm{F}[2,26]=3.4, p<.05$ ), but no significant effect of Shock Duration, $\mathrm{F}[2,52]=2.5$, ns) was observed. Because of the effect of lofexidine on inactive lever responding, a change score (active lever - inactive lever responses) analysis was conducted. This analysis essentially replicated that of the active lever (data not shown). Thus, after taking into account potential nonspecific effects of lofexidine on responding, the drug effectively attenuated footshock-induced reinstatement.

Session 2. No significant effects were found for the effect of lofexidine pretreatment $(7 \mathrm{hr})$ on active lever responses (Lofexidine Dose, $\mathrm{F}[2,26]=2.2$, ns) or for a residual effect of footshock (Shock Duration, F[2,52] $=0.4$, ns) given prior to Session 1. In addition, no significant effects were observed for responses on the inactive lever (data not shown).
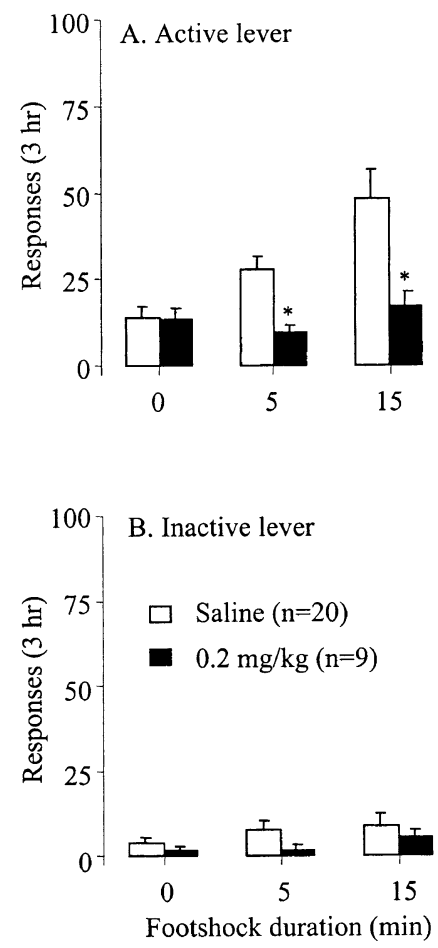

Figure 4. Experiment 1: Second test for stress-induced reinstatement - acute lofexidine injections. Mean \pm SEM number of non-reinforced responses on (A) the previously active lever and on (B) the inactive lever during the first 3-hr daily session (Session 1) after no shock and exposure to 5 and 15 min of intermittent footshock. Rats previously pretreated with lofexidine $(n=20)$ during the training and extinction phases, and during the first test for reinstatement were given saline injections. Rats previously pretreated with saline $(n=9)$ were given lofexidine injections. ${ }^{*}$ Different from the saline condition, $p<.05$.

SeCOnd Test For Reinstatement. Session 1. Exposure to footshock increased responding on the previously active lever in the saline-treated rats (Shock Duration, $\mathrm{F}[2,54]=5.5, p<.01)$. This effect was attenuated by lofexidine (Lofexidine Dose, $\mathrm{F}[1,27]=8.6, p<.01$; Shock Duration by Lofexidine Dose, $\mathrm{F}[2,54]=3.4, p<.05$ ). No significant effects were found for responding on the inactive lever: Lofexidine Dose $(\mathrm{F}[1,27]=1.9, \mathrm{~ns})$ and Shock Duration $(\mathrm{F}[2,54]=1.0, \mathrm{~ns})$.

Session 2. No significant effects were found for lofexidine pretreatment $(7 \mathrm{hr}$ ) on active lever responses (Lofexidine Dose, $\mathrm{F}[1,23]=2.2$, ns), or for a residual effect of footshock (Shock Duration, $\mathrm{F}[2,46]=1.0$, ns) given prior to Session 1. In addition, no significant effects were observed for inactive lever responses (data not shown).

\section{Experiment 2: Cue-Induced Reinstatement}

Training Phase. Rats rapidly acquired speedball selfadministration during days 1-5 of training (data not 
shown). The effect of lofexidine or saline on speedball self-administration during Session 1 of days 7-10 of training is presented in Figure $1 b$.

SESSION 1. Lofexidine pretreatment $(1 \mathrm{hr})$ had no effect on speedball infusions earned $(F[2,19]=1.8, n s)$. Lofexidine also had no effect on inactive lever responses (data not shown).

SESSION 2. Lofexidine pretreatment $(7 \mathrm{hr})$ had no effect on speedball infusions earned $(\mathrm{F}[2,19]=1.8$, ns) or on inactive lever responses (data not shown).

Extinction Phase. The effect of lofexidine and saline on extinction behavior during Session 1 is presented in Figure $2 \mathrm{~b}$. During the extinction phase, the drug syringes were removed and the tone + light cue was not presented.

SESSION 1. Lofexidine pretreatment $(1 \mathrm{hr})$ had no effect on responses on the previously active lever (Lofexidine Dose, $\mathrm{F}[2,19]=2.3$, ns). An effect of Extinction Day $(\mathrm{F}[10,190]=27.9, p<.01)$ was observed; all groups reduced lever pressing over time. However, despite the lack of overall statistical significance, active lever responses on day 2 of extinction were higher in the saline group than in the lofexidine groups $(p<.05)$. This effect of lofexidine, which was not observed in Experiment 1, may be due to the fact that in Experiment 2 lever presses did not lead to the delivery of the drugpaired cues during extinction.

Lofexidine pretreatment had some effect on responses on the inactive lever (Lofexidine Dose, $\mathrm{F}[2,19]=$ $8.7, p<.01)$. This effect is due to the lower responses on this lever in rats pretreated with lofexidine $(0.1 \mathrm{mg} / \mathrm{kg}$ : $0.6 \pm 0.4$ responses $/ 3 \mathrm{hr} ; 0.2 \mathrm{mg} / \mathrm{kg}: 1.2 \pm 0.4 \mathrm{re}-$ sponses/ $3 \mathrm{hr}$; mean responses on days $1-11$ of extinction) than in rats treated with saline $(5.0 \pm 1.4$ responses $/ 3 \mathrm{hr})$. No effect of Extinction Day $(\mathrm{F}[10,190]=$ 0.9 , ns) was observed for responses on the inactive lever.

SESSION 2. Lofexidine pretreatment $(7 \mathrm{hr}$ ) had no effect on responses on the previously active lever $(\mathrm{F}[2,19]=1.2, \mathrm{~ns})$ or on the inactive lever (data not shown).

Test for Reinstatement. The effect of lofexidine or saline on responses on the previously active lever and the inactive lever during tests for reinstatement are presented in Figure 5. During the test for cue-induced reinstatement, lever presses led to presentations of the tone + light cue during Session 1. A regular extinction session was conducted during Session 2 (i.e., lever presses did not lead to the delivery of the conditioned cue).

SESSION 1. Exposure to the conditioned cue increased responding on the previously active lever (Cue Exposure, $\mathrm{F}[1,19]=23.5, p<.01)$. This effect was not attenuated by lofexidine (Lofexidine Dose, $\mathrm{F}[2,19]=0.3$, ns; Cue Exposure by Lofexidine Dose, F[2,19] = 0.7, ns). No significant effects were observed for responses on the inactive lever.
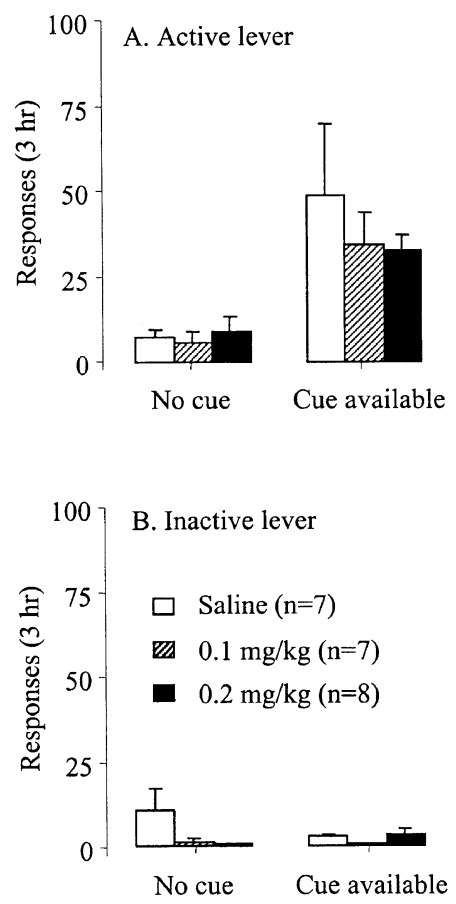

Figure 5. Experiment 2: Test for cue-induced reinstatement. Mean \pm SEM number of non-reinforced responses on (A) the previously active lever and on (B) the inactive lever during the first 3-hr daily session (Session 1) when the tone + light cue was not available (No Cue) or when lever presses resulted in the delivery of the cue (Cue Available). Tests were conducted $24 \mathrm{hr}$ apart. Rats were pretreated with saline or lofexidine during days 7-10 of training, the extinction phase, and during testing. Saline or lofexidine injections were given $1 \mathrm{hr}$ prior to the start of Session 1 ( $n=7-8$ per dose).

SESSION 2. No significant effects were observed for responses on the active or the inactive levers: Lofexidine Dose, $\mathrm{F}[2,19]=0.3$, and $\mathrm{F}[2,19]=3.3$, ns, respectively (data not shown).

Finally, Figure 6 shows the number of infusions in saline-pretreated and lofexidine-pretreated rats on Session 1 during of days 24 and 25 of the experiment. During these days, the rats lever pressed for speedball infusions. As can be seen in Figure 6, which also includes the data during days 6-10 of training for these rats, repeated lofexidine injections during training, extinction and testing did not alter subsequent speedball self-administration behavior.

\section{Effect of Lofexidine on Footshock Sensitivity and Body Weight}

No group differences were observed for body weight measurements taken throughout the experiments (data not shown). In addition, regardless of the experimental conditions, the rats did not lose weight after drug cessa- 


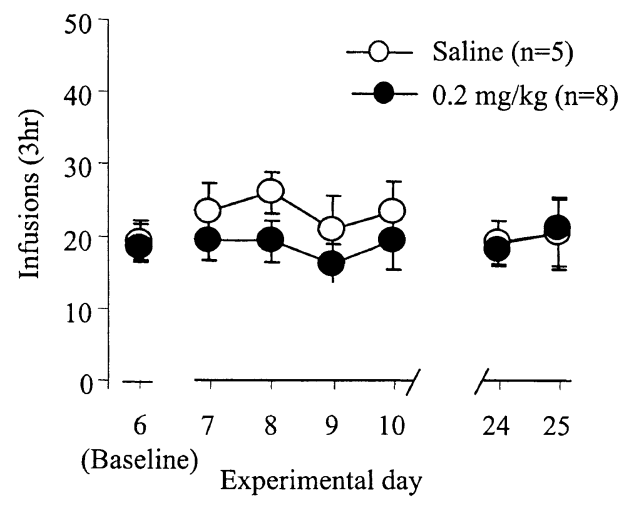

Figure 6. Experiment 2: Effect of repeated lofexidine treatment on resumption of speedball self- administration behavior. Mean \pm SEM number of speedball infusions on the first 3-hr daily session (Session 1) during days 6 to 10 of the training phase and on days 24-25 of the experiment when rats were given access to speedball. Data are from rats injected with saline $(n=5)$ or lofexidine $(n=8)$ one hr prior to Session 1 on days 7 to 25 of the experiment.

tion, a reliable measure of opioid withdrawal (Bhargava 1994). Lofexidine $(0.2 \mathrm{mg} / \mathrm{kg})$ had no effect on threshold sensitivity to footshock (saline pretreatment, $0.33 \pm 0.05 \mathrm{~mA}, n=8$; lofexidine pretreatment, $0.33 \pm$ $0.04 \mathrm{~mA} ; n=10)$.

\section{DISCUSSION}

The major finding in the present report is that repeated treatment with lofexidine selectively attenuates footshock-induced reinstatement of speedball seeking, but not cue-induced reinstatement. The effect of repeated lofexidine on footshock stress-induced reinstatement extends the findings that acute exposure to alpha-2 adrenoceptor agonists attenuate footshock stress-induced reinstatement in rats with a history of heroin $(0.1 \mathrm{mg} / \mathrm{kg} /$ inf) or cocaine $(0.5 \mathrm{mg} / \mathrm{kg} / \mathrm{inf})$ self-administration (Erb et al. 2000; Shaham et al. 2000b). Furthermore, the dose response effect of repeated lofexidine in the present study was similar to that observed with acute lofexidine in cocaine-trained rats (Erb et al. 2000). Finally, the high dose of lofexidine had similar effects on stress-induced reinstatement in the first (repeated drug injections) and the second (acute drug injections) test for reinstatement (Figures 3 and 4). Together, these data suggest that tolerance does not develop to the effect of lofexidine on footshock stress-induced reinstatement after repeated administration.

\section{Methodological Considerations}

During the first test for footshock stress-induced reinstatement, lofexidine not only decreased responding on the previously active lever, but also somewhat decreased responding on the inactive lever. Thus, it is possible that lofexidine decreases footshock-induced reinstatement by interfering with motor performance. Lofexidine, however, had only minimal effects on lever pressing during the training and extinction phases. In addition, lofexidine did not alter cue-induced reinstatement or resumption of speedball self-administration after 17 days of lofexidine treatment (Figure 6). Thus, it is unlikely that effect of lofexidine on stress-induced reinstatement is due to motor deficits.

Alpha-2 adrenoceptor agonists are also known to induce analgesia (Codd et al. 1995). Therefore, lofexidine may block stress-induced reinstatement by increasing pain threshold. This seems unlikely, however, as we found that the high dose of lofexidine has no effect on threshold sensitivity to footshock. Another possibility is that lofexidine attenuates footshock-induced reinstatement by disrupting stimulus control. Lofexidine somewhat increased inactive lever responses during the extinction phase of Experiment 1, an observation that may indicate a loss of stimulus control. However, lofexidine did not alter responding on the inactive lever during the training phase, somewhat decreased responding on this lever during tests for footshock-induced reinstatement, and did not alter cue-induced reinstatement. Thus, it is not likely that lofexidine attenuates stressinduced reinstatement by disrupting stimulus control.

Finally, we used one dose combination of speedball and rats were trained under a continuous reinforcement schedule. Under these conditions, lofexidine had minimal effect on speedball self-administration and extinction behavior. These negative findings, however, should be interpreted with caution because the effects of pharmacological manipulations on operant behaviors maintained by drugs and non-drug reinforcers are dependent on baseline rates of responding (Sanger and Blackman 1976; Witkin 1994). Thus, an important topic for future research is to determine whether the present set of data with lofexidine generalizes to other combinations of speedball doses and other schedules of reinforcement.

\section{Implications of the Findings to the Mechanisms Underlying Relapse to Speedball Seeking}

The observation that lofexidine attenuates stress-induced reinstatement of drug seeking, but not speedball selfadministration or cue-induced reinstatement is in agreement with the idea that different mechanisms underlie the unconditioned reinforcing and reinstating effects of drugs, drug-reinforced behavior controlled by conditioned cues, and stress-induced reinstatement. For example, dopamine (DA) is involved in the reinforcing and reinstating effects of priming injections of heroin 
and cocaine (Self and Nestler 1998; Stewart 1984; Wise 1996) and cocaine seeking induced by drug cues (Pilla et al. 1999). DA, however, appears to be only indirectly involved in stress-induced reinstatement (Shaham and Stewart 1996). In addition, opioid receptors contribute to the reinforcing (Ettenberg et al. 1982; Herz 1997) and reinstating (Lê et al. 1999; Shaham and Stewart 1996; Stewart 1984) effects of heroin and alcohol. However, the opioid antagonist, naltrexone, has no effect on footshock stress-induced reinstatement of alcohol and heroin seeking (Lê et al. 1999; Shaham and Stewart 1996).

On the other hand, corticotropin-releasing factor (CRF) receptor antagonists (Erb et al. 1998; Shaham et al. 1997), alpha-2 adrenoceptor agonists (Erb et al. 2000), and the 5-HT reuptake blocker, fluoxetine (Lê et al. 1999), attenuate footshock-induced reinstatement, while having minimal effects on drug priming-induced reinstatement.

We found that reexposure to drug cues reinstates speedball seeking. The mechanisms involved in this effect, however, are not known. Drug cues are thought to reinstate drug seeking by inducing a "drug-like" state, similar to that induced by the self-administered drug (Stewart et al. 1984). As mentioned, activation of both opioid and DA receptors is involved in the reinforcing effects of speedball (Hemby et al. 1996; Mello and Negus 1999). Furthermore, during speedball self-administration, DA levels in the NAc are dramatically elevated (Hemby et al. 1999). Thus, an increase in DA utilization in the NAc may contribute to cue-induced reinstatement. In agreement with this idea, studies with rats using high-speed chronoamperometry or microdialysis reported elevations in the DA signal in the NAc after presentation of cues previously paired with cocaine (Gratton and Wise 1994; Kiyatkin and Stein 1996; Weiss et al. 2000) or amphetamine (Di Ciano et al. 1998) selfadministration.

On the other hand, in another microdialysis study in rats, cues paired with cocaine self-administration had no effect on DA levels in the NAc (Neisewander et al. 1996). In addition, a study with rhesus monkeys found that while cocaine self-administration elevates DA in the mesolimbic striatum, cues associated with cocaine self-administration have no impact on DA release (Bradberry et al. 2000). Furthermore, reversible inactivation of the NAc with tetrodotoxin blocks resumption of cocaine seeking induced by reexposure to cocaine, but fails to alter drug cues-induced relapse in rats (Grimm and See 2000). Interestingly, inactivation of the basolateral amygdala (BLA) has an opposite effect.

Finally, exposure to cues previously paired with cocaine self-administration increases DA utilization in the amygdala of rats (Weiss et al. 2000). These data, and those of the effect of systemic (Alleweireldt et al. 2000) or intra-BLA D1-like receptor antagonists (See et al. 2001) on cue-induced reinstatement, suggest that DA in this brain area is involved in relapse induced by drug cues. Thus, despite the large increase in DA release in the NAc during speedball self-administration (Hemby et al. 1999), it remains to be seen whether speedballpaired cues can induce DA release in this area, and whether this putative activation by the drug cues is associated with drug seeking.

Two important questions that should be addressed are the receptor type(s) on which lofexidine acts to attenuate stress-induced reinstatement and the site(s) of action of lofexidine in the brain. Lofexidine binds to both alpha-2 adrenoceptors and imidazoline type-1 receptors (Ernsberger et al. 1995). It is unlikely, however, that the action of lofexidine on the imidazoline receptors contributes to stress-induced reinstatement. It was found that the alpha-2 adrenoceptor agonist, guanabenz, which has low affinity to the imidazoline type- 1 receptors (Piletz et al. 1994), attenuates stress-induced reinstatement of cocaine seeking (Erb et al. 2000). In addition, based on recent microdialysis data (Erb et al. 2000) and previous data using electrophysiological methods (Cooper et al. 1986), it is likely that the alpha-2 adrenoceptor agonists at the doses used in our studies attenuate stress-induced reinstatement by acting on presynaptic receptors. It cannot be ruled out, however, that lofexidine and the other alpha-2 adrenoceptor agonists have their effects on the less sensitive postsynaptic receptors.

As for the site(s) of action of lofexidine, it is likely that its effect on stress-induced reinstatement is centrally mediated. The systemic effects of clonidine and lofexidine on stress-induced reinstatement of cocaine seeking are not mimicked by peripheral injections of ST-91 (Erb et al. 2000). ST-91 is a charged analogue of clonidine, which does not effectively cross the blood brain barrier (Scriabine et al. 1975). In addition, infusions of clonidine into the brain ventricles were found to mimic the effect of systemic injections of the drug on stress-induced reinstatement (Shaham et al. 2000a). Furthermore, we found that 6-OHDA lesions of the ventral NE pathway, which selectively destroys lateral tegmental NE neurons (Hansen et al. 1980), attenuate footshock-induced reinstatement of heroin seeking, whereas injections of clonidine or ST-91 directly into the locus coeruleus were not effective (Shaham et al. $2000 \mathrm{~b})$. One major brain area that is innervated by the lateral tegmental NE neurons is the bed nucleus of the stria terminalis (BNST). The lateral tegmental NE neurons form synaptic contact with CRF-containing neurons in the ventrolateral BNST (Phelix et al. 1994), and injections of a CRF receptor antagonist into this site block footshock-induced reinstatement of cocaine seeking (Erb and Stewart 1999). Thus, lofexidine and clonidine may attenuate stress-induced reinstatement via their action on the NE projections to the BNST (Shaham et al. 2000a). 


\section{Clinical Implications}

The present data may have clinical implications. As mentioned, relapse prevention is complicated because many drug addicts use both heroin and cocaine, including the speedball combination, and no effective medications exist for the prevention of relapse in these polydrug users (Schottenfeld et al. 1997; Schutz et al. 1998). The present data were obtained under conditions that to some degree are more relevant to the situation in humans than those used in previous studies, in which the alpha-2 adrenoceptor agonists were given acutely during tests for reinstatement to rats trained to self-administer either heroin or cocaine. On the other hand, in the present report lofexidine was given repeatedly during training, extinction and testing to rats that self-administered a heroin-cocaine mixture. In the typical clinical situation, medications are often given for long periods of time, during the different phases of the addiction process, to people who use more than one drug of abuse (O'Brien 1997). Thus, to the extent that relapse to drugs in humans can be studied with the reinstatement method in laboratory animals, and to the extent that stressful life events contribute to relapse in humans (Brown et al. 1995; Kosten et al. 1986; Sinha et al. 1999), the present data may provide a rationale for the use of lofexidine to prevent stress-induced relapse in polydrug users. The present preclinical data, however, suggest that lofexidine is not likely to prevent relapse induced by reexposure to drug-related cues or to speedball itself.

\section{ACKNOWLEDGMENTS}

This study was supported by NIDA/IRP. D.H. and J.Y. contributed equally to this manuscript. We thank Drs. Kenzie Preston and David Epstein for helpful comments.

\section{REFERENCES}

Aghajanian GK, VanderMaelen CP (1982): Alpha 2-adrenoceptor-mediated hyperpolarization of locus coeruleus neurons: Intracellular studies in vivo. Science 215:13941396

Alleweireldt AT, Weber SM, Kirschner KF, Bullock B, Neisewander JL (2000): Blockade of D1 dopamine receptors attenuates cue reinstatement of cocaine-seeking behavior. Soc Neurosci Abstr 26:793

Bhargava HN (1994): Diversity of agents that modify opioid tolerance, physical dependence, abstinence syndrome and self-administration behavior. Pharmacol Rev 46:293-324

Bradberry CW, Barrett-Larimore RL, Jatlow P, Rubino SR (2000): Impact of self-administered cocaine and cocaine cues on extracellular dopamine in mesolimbic and sen- sorimotor striatum in rhesus monkeys. J Neurosci 20:3874-3883

Brown SA, Vik PW, Patterson TL, Grant I, Schuckit MA (1995): Stress, vulnerability and adult alcohol relapse. J Stud Alcohol 56:538-545

Carter AJ (1997): Hippocampal noradrenaline release in awake, freely moving rats is regulated by alpha-2 adrenoceptors but not by adenosine receptors. J Pharmacol Exp Ther 281:648-654

Childress AR, Ehrman R, Rohsenow DJ, Robbins SJ, O’Brien CP (1992): Classically conditioned factors in drug dependence. In Lowinson JW, Luiz P, Millman RB, Langard G (eds), Substance Abuse: A Comprehensive Textbook. Baltimore, Williams and Wilkins, pp 56-69

Codd EE, Press JB, Raffa RB (1995): Alpha 2-adrenoceptors vs. imidazoline receptors: Implications for alpha-2-mediated analgesia and other non-cardiovascular therapeutic uses. Life Sci 56:63-74

Cooper JR, Bloom FE, Roth RH (1986): The Biochemical Basis of Neuropharmacology, 5th ed. Oxford, Oxford University Press

Davis WM, Smith SG (1976): Role of conditioned reinforcers in the initiation, maintenance and extinction of drugseeking behavior. Pavlovian J Biol Sci 11:222-236

De Vries TJ, Schoffelmeer AN, Binnekade R, Vanderschuren LJ (1999): Dopaminergic mechanisms mediating the incentive to seek cocaine and heroin following longterm withdrawal of IV drug self-administration. Psychopharmacology 143:254-260

de Wit H (1996): Priming effects with drugs and other reinforcers. Exp Clin Psychopharmacol 4:5-10

Di Ciano P, Blaha CD, Phillips AG (1998): Conditioned changes in dopamine oxidation currents in the nucleus accumbens of rats by stimuli paired with self-administration or yoked-administration of d-amphetamine. Eur J Neurosci 10:1121-1127

Duvauchelle CL, Sapoznik T, Kornetsky C (1998): The synergistic effects of combining cocaine and heroin ("speedball") using a progressive-ratio schedule of drug reinforcement. Pharmacol Biochem Behav 61:297-302

Erb S, Hitchcott PK, Rajabi H, Mueller D, Shaham Y, Stewart J (2000): Alpha-2 adrenergic agonists block stressinduced reinstatement of cocaine seeking. Neuropsychopharmacology 23:138-150

Erb S, Shaham Y, Stewart J (1996): Stress reinstates cocaineseeking behavior after prolonged extinction and drugfree periods. Psychopharmacology 128:408-412

Erb S, Shaham Y, Stewart J (1998): The role of corticotropinreleasing factor and corticosterone in stress- and cocaine-induced relapse to cocaine seeking in rats. J Neurosci 14:5529-5536

Erb S, Stewart J (1999): A role for the bed nucleus of the stria terminalis, but not the amygdala, in the effects of corticotropin-releasing factor on stress-induced reinstatement of cocaine seeking. J Neurosci 19:RC35

Ernsberger P, Graves ME, Graff LM, Zakieh N, Nguyen P, Collins LA, Westbrooks KL, Johnson GG (1995): I1-imidazoline receptors. Definition, characterization, distribution, and trans-membrane signaling. Ann N Y Acad Sci 763:22-42 
Ettenberg A, Pettit HO, Bloom FE, Koob GF (1982): Heroin and cocaine intravenous self-administration in rats: mediation by separate neural systems. Psychopharmacology 78:204-209

Gold MS, Kleber HD (1979): A rationale for opiate withdrawal symptomatology. Drug Alcohol Dependence 4:419-423

Gratton A, Wise RA (1994): Drug- and behavior-associated changes in dopamine-related electrochemical signals during intravenous cocaine self-administration in rats. J Neurosci 14:4130-4146

Grimm JW, See RE (2000): Dissociation of primary and secondary reward-relevant limbic nuclei in an animal model of relapse. Neuropsychopharmacology 22:473479

Hansen S, Stanfield EJ, Everitt BJ (1980): The role of ventral bundle noradrenergic neurones in sensory components of sexual behaviour and coitus-induced pseudopregnancy. Nature 286:152-154

Hemby SE, Co C, Dworkin SI, Smith JE (1999): Synergistic elevations in nucleus accumbens extracellular dopamine concentrations during self-administration of cocaine/heroin combinations (Speedball) in rats. J Pharmacol Exp Ther 288:274-280

Hemby SE, Smith JE, Dworkin SI (1996): The effects of eticlopride and naltrexone on responding maintained by food, cocaine, heroin and cocaine/heroin combinations in rats. J Pharmacol Exp Ther 277:1247-1258

Herman BH, O'Brien CP (1997): Clinical medications development for opiate addiction: Focus on nonopioid and opioid antagonists for the amelioration of opiate withdrawal symptoms and relapse prevention. Sem Neurosci 9:158-172

Herz A (1997): Endogenous opioid systems and alcohol addiction. Psychopharmacology 129:99-111

Hoffman JA, Klein H, Clark DC, Boyd FT (1998): The effect of entering drug treatment on involvement in HIVrelated risk behaviors. Am J Drug Alcohol Abuse 24:259-284

Kiyatkin EA, Stein EA (1996): Conditioned changes in nucleus accumbens dopamine signal established by intravenous cocaine in rats. Neurosci Lett 211:73-76

Kosten TR, Rounsaville BJ, Kleber HD (1986): A 2.5-year follow-up of depressions, life crises, and treatment effects on abstinence among opioid addicts. Arch Gen Psychiatry 43:733-739

Lê AD, Poulos CX, Harding S, Watchus W, Juzytsch W, Shaham Y (1999): Effects of naltrexone and fluoxetine on alcohol self-administration and reinstatement of alcohol seeking induced by priming injections of alcohol and exposure to stress in rats. Neuropsychopharmacology 21:435-444

Lin SK, Strang J, Su LW, Tsai CJ, Hu WH (1997): Doubleblind randomised controlled trial of lofexidine versus clonidine in the treatment of heroin withdrawal. Drug Alcohol Depend 48:127-133

Ludwig AM, Wikler A, Stark LH (1974): The first drink. Psychobiological aspects of craving. Arch Gen Psychiatry 30:539-547

Meil WM, See RE (1996): Conditioned cued recovery of responding following prolonged withdrawal from self- administered cocaine in rats: An animal model of relapse. Behav Pharmacol 7:754-763

Mello NK, Negus SS (1999): Effects of flupenthixol and quadazocine on self-administration of speedball combinations of cocaine and heroin by rhesus monkeys. Neuropsychopharmacology 21:575-585

Mello NK, Negus SS, Lukas SE, Mendelson JH, Sholar JW, Drieze JJ (1995): A primate model of polydrug abuse: Cocaine and heroin combinations. J Pharmacol Exp Ther 274:1325-1337

Mendelson JH, Mello NK (1996): Management of cocaine abuse and dependence. N Engl J Med 334:965-972

Negus SS, Mello NK (1998): The effects of buprenorphine on self-administration of cocaine and heroin "speedball" combinations and heroin alone by rhesus monkeys. J Pharmacol Exp Ther 285:444-456

Neisewander JL, O'Dell LE, Tran-Nguyen LT, Castaneda E, Fuchs RA (1996): Dopamine overflow in the nucleus accumbens during extinction and reinstatement of cocaine self-administration behavior. Neuropsychopharmacology 15:506-514

O'Brien CP (1997): A range of research-based pharmacotherapies for addiction. Science 278:66-70

Phelix CF, Liposits Z, Paull WK (1994): Catecholamine-CRF synaptic interaction in a septal bed nucleus: Afferents of neurons in the bed nucleus of the stria terminalis. Brain Res Bull 33:109-119

Piletz JE, Halaris A, Ernsberger PR (1994): Psychopharmacology of imidazoline and alpha 2-adrenergic receptors: Implications for depression. Crit Rev Neurobiol 9:29-66

Pilla M, Perachon S, Sautel F, Garrido F, Mann A, Wermuth CG, Schwartz JC, Everitt BJ, Sokoloff P (1999): Selective inhibition of cocaine-seeking behaviour by a partial dopamine D3 receptor agonist. Nature 400:371-375

Rowlett JK, Wilcox KM, Woolverton WL (1999): Self-administration of cocaine-heroin combinations by rhesus monkeys: Antagonism by naltrexone. J Pharmacol Exp Ther 286:61-69

Sanger DJ, Blackman DE (1976): Rate-dependent effects of drugs: A review of the literature. Pharmacol Biochem Behav 4:73-83

Schottenfeld RS, Pakes JR, Oliveto A, Zeidonis D, Kosten TR (1997): Buprenorphine vs. methadone maintenance treatment for concurrent opioid dependence and cocaine abuse. Arch Gen Psychiatry 54:713-720

Schutz CG, Vlahov D, Anthony JC, Graham NM (1998): Comparison of self-reported injection frequencies for past 30 days and 6 months among intravenous drug users. J Clin Epidemiol 47:191-195

Scriabine A, Sweet CS, Ludde CT, Stavorski JM, Wenger HC, Bohidar NR (1975): Some cardiovascular effects of ST-91 and clonidine. Eur J Pharmacol 43:333-341

See RE, Kruzich PJ, Grimm JW (2001): Dopamine, but not glutamate, receptor blockade in the basolateral amygdala attenuates conditioned reward in an animal model of relapse to cocaine seeking behavior. Psychopharmacology 154:301-310

Self DW, Nestler EJ (1998): Relapse to drug-seeking: Neural and molecular mechanisms. Drug Alcohol Depend 51:49-69 
Shaham Y, Erb S, Stewart J (2000a): Stress-induced relapse to heroin and cocaine seeking in rats: A review. Brain Res Rev 33:13-33

Shaham Y, Funk D, Erb S, Brown TJ, Walker CD, Stewart J (1997): Corticotropin-releasing factor, but not corticosterone, is involved in stress-induced relapse to heroinseeking in rats. J Neurosci 17:2605-2614

Shaham Y, Highfield D, Delfs JM, Leung S, Stewart J (2000b): Clonidine blocks stress-induced reinstatement of heroin seeking in rats: An effect independent of the locus coeruleus noradrenergic neurons. Eur J Neurosci 12:292-302

Shaham Y, Stewart J (1995): Stress reinstates heroin selfadministration behavior in drug-free animals: An effect mimicking heroin, not withdrawal. Psychopharmacology 119:334-341

Shaham Y, Stewart J (1996): Effects of opioid and dopamine receptor antagonists on relapse induced by stress and reexposure to heroin in rats. Psychopharmacology 125:385-391

Sinha R, Catapano D, O'Mally S (1999): Stress-induced craving and stress responses in cocaine dependent individuals. Psychopharmacology 142:343-351

Stanford SC (1995): Central noradrenergic neurones and stress. Pharmacol Ther 68:297-342

Stewart J (1984): Reinstatement of heroin and cocaine selfadministration behavior in the rat by intracerebral application of morphine in the ventral tegmental area. Pharmacol Biochem Behav 20:917-923
Stewart J, de Wit H (1987): Reinstatement of drug-taking behavior as a method of assessing incentive motivational properties of drugs. In Bozarth MA (ed), Methods of Assessing the Reinforcing Properties of Abused Drugs. New York, Springer-Verlag, pp 211-227

Stewart J, de Wit H, Eikelboom R (1984): Role of unconditioned and conditioned drug effects in the self-administration of opiates and stimulants. Psychol Rev 91:251268

Tran-Nguyen TL, Fuchs RA, Coffey GP, O’Dell LE, Baker DA, Neisewander JL (1998): Time-dependent changes in cocaine-seeking behavior and dopamine overflow in the amygdala during cocaine withdrawal. Neuropsychopharmacology 19:48-59

Weiss F, Maldonado-Vlaar CS, Parsons LH, Kerr TM, Smit DL, Ben-Shahar O (2000): Control of cocaine-seeking behavior by drug-associated stimuli in rats: effects on recovery of extinguished operant-responding and extracellular dopamine levels in amygdala and nucleus accumbens. Proc Natl Acad Sci U S A 97:4321-4326

Wise RA (1996): Neurobiology of addiction. Curr Opin Neurobiol 6:243-251

Witkin J (1994): Pharmacotherapy of cocaine abuse: Preclinical development. Neurosci Biobehav Rev 1:121-142

Zernig G, O'Laughlin IA, Fibiger HC (1997): Nicotine and heroin augment cocaine-induced dopamine overflow in nucleus accumbens. Eur J Pharmacol 337:1-10 